\title{
BACTERIOPHAGE THERAPY AS A TREATMENT STRATEGY FOR ORTHOPAEDIC-DEVICE-RELATED INFECTIONS: WHERE DO WE STAND?
}

\author{
J. Onsea ${ }^{1,2, *}$, J. Wagemans ${ }^{3}$, J.P. Pirnay ${ }^{4}$, M. Di Luca 5 , M. Gonzalez-Moreno ${ }^{6}$, R. Lavigne ${ }^{3}$, A. Trampuz ${ }^{6}$, \\ T.F. Moriarty ${ }^{7}$ and W-J. Metsemakers ${ }^{1,2}$ \\ ${ }^{1}$ Department of Trauma Surgery, University Hospitals Leuven, Leuven, Belgium \\ ${ }^{2}$ Department of Development and Regeneration, KU Leuven, Leuven, Belgium \\ ${ }^{3}$ Laboratory of Gene Technology, KU Leuven, Leuven, Belgium \\ ${ }^{4}$ Laboratory for Molecular and Cellular Technology, Queen Astrid Military Hospital, Brussels, Belgium \\ ${ }^{5}$ Department of Biology, University of Pisa, Pisa, Italy \\ ${ }^{6}$ Centre for Musculoskeletal Surgery, Charité - Universitätsmedizin Berlin, corporate member of Freie \\ Universität Berlin, Humboldt-Universität zu Berlin and Berlin Institute of Health, Berlin, Germany \\ ${ }^{7}$ AO Research Institute Davos, Davos, Switzerland
}

\begin{abstract}
Antibiotic resistance represents a key challenge of the $21^{\text {st }}$ century. Since the pipeline of new antibiotics in development is limited, the introduction of alternative antimicrobial strategies is urgently required.

Bacteriophage therapy, the use of bacterial viruses to selectively kill bacterial pathogens, is re-emerging as a potential strategy to tackle difficult-to-treat and multidrug-resistant pathogens. The last decade has seen a surge in scientific investigation into bacteriophage therapy, including targeting orthopaedic-devicerelated infections (ODRIs) in several successful case studies. However, pharmacological data, knowledge on the interplay with the immune system and, especially in ODRIs, the optimal local application strategy and treatment outcomes remain scarce.

The present review reports the state-of-the-art in bacteriophage therapy in ODRIs and addresses the hurdles in establishing bacteriophage therapy under good clinical practice guidelines. These hurdles include a lack of data concerning bacteriophage production, processing, administration and dosing, as well as followup clinical monitoring reports. To overcome these challenges, an integrated clinical approach is required, supported by comprehensive legislature to enable expansive and correctly implemented clinical trials.
\end{abstract}

Keywords: Bacteriophage therapy, clinical application, orthopaedic-device-related infections, current evidence.

*Address for correspondence: Jolien Onsea, Department of Trauma Surgery, University Hospitals Leuven, Herestraat 49, 3000 Leuven, Belgium.

Telephone number: +32 16342041 Email: jolien.onsea@uzleuven.be

Copyright policy: This article is distributed in accordance with Creative Commons Attribution Licence (http://creativecommons.org/licenses/by-sa/4.0/).

\section{List of Abbreviations}

AMR

API

BAL

BMP

BREX

CFU

CRISPR

E. faecalis antimicrobial resistance

active pharmaceutical ingredient

Belgian approved laboratory

bone morphogenetic protein

bacteriophage exclusion

colony-forming unit

clustered regularly interspaced short

palindromic repeats

Enterococcus faecalis
EMA

FAMHP

FDA

FRI

GCP

GMP

HPMC

MDR-PA

MOI

MRSA
European Medicines Agency

Federal Agency for Medicines and Health Products

Food and Drug Administration

fracture-related infection

good clinical practices good manufacturing practices hydroxypropyl methylcellulose multidrug-resistant $P$. aeruginosa multiplicity of infection methicillin-resistant $S$. aureus 
MSCRAMMs microbial surface components recognising adhesive matrix molecules

$\begin{array}{ll}\text { ODRI } & \begin{array}{l}\text { orthopaedic-device-related infection } \\ \text { osteomyelitis }\end{array} \\ \text { PM } & \text { Pseudomonas aeruginosa } \\ \text { PFU } & \text { plaque-forming unit } \\ \text { PJI } & \text { prosthetic joint infection } \\ \text { RCT } & \text { randomised controlled trial } \\ \text { S. aureus } & \text { Staphylococcus aureus } \\ \text { S. epidermidis } & \text { Staphylococcus epidermidis } \\ \text { WHO } & \text { World Health Organization }\end{array}$

\section{Introduction}

An infection is one of the major complications that scientists and clinicians face in the orthopaedic field today. Although the rate of infectious complications after elective orthopaedic surgery remains low ( $3 \%$ ) (Cram et al., 2012), the incidence continues to rise. This is due not only to the annual increase in elective joint replacement surgeries (Kurtz et al., 2012) but also to an increased number of operatively treated fractures (Patel et al., 2015). Moreover, the overall infection rate in musculoskeletal trauma remains high and can rise up to $25-30 \%$ after severe open fractures (Papakostidis et al., 2011).

\section{The role of biofilms in ODRIs}

Biofilm formation is broadly acknowledged to be the primary challenge in preventing and treating ODRIs (Nishitani et al., 2015). The ability of bacteria to establish such chronic infections, and the human inability to deal with them, is directly associated with biofilm formation. Indeed, in biofilms an environment is created in which bacteria can grow and persist while being protected against the patient's immune response and from any antimicrobial therapy (Brady et al., 2008). The formation of the biofilm's complex structure is a multi-step process that begins with the initial attachment of bacteria to an implant's surface through one or more cellwall-associated adhesins or MSCRAMMs, which recognise numerous mammalian structures (Patti et al., 1994). Next, surface-bound bacteria enter a robust proliferation phase and secrete matrix components, including carbohydrate polymers and proteins (Nishitani et al., 2015). Several factors are responsible for antibiotic tolerance within biofilms, including a restricted penetration of antimicrobials into the biofilm, a decreased bacterial growth rate and the expression of possible resistance genes (Costerton et al., 1999; Gilbert et al., 1997). Alone or in combination, these factors explain why biofilm formation leads to persistent infections that are resistant to conventional antimicrobial treatment.

One of the major challenges for the treatment of ODRIs is the reimplantation of the device, which in most cases is required for the patient's functionality. During the explantation of the contaminated device and radical debridement, it is very difficult to completely eradicate or resect all biofilm-residing microorganisms from the infected area. In fact, the biofilm may be harboured on tiny fragments of necrotic bone, known as sequesters, and may also reside within the cortical bone itself (de Mesy Bentley et al., 2018). During reimplantation, the biofilmresiding bacteria may be liberated and re-enter their planktonic growth phase, resulting in reinfection (Moriarty et al., 2016).

\section{Treatment difficulties and current challenges}

As stated by the WHO, AMR is one of the biggest threats to global health today $(\mathrm{WHO}, 2015)$. Pathogens such as MRSA and MDR-PA are emerging as a significant threat in both the hospital and community environment (Boucher and Corey, 2008; van Duin and Paterson, 2016). Within the healthcare setting alone, for example, MRSA infections are estimated to affect more than 150,000 patients annually in the EU, resulting in additional in-hospital costs of $€ 380$ million for the EU healthcare systems (Kock et al., 2010). Even with an adequate treatment, MRSA infections are still associated with a higher mortality and increased financial costs relative to sensitive equivalents (Haddadin et al., 2002; Moriarty et al., 2016; Salgado et al., 2007; Teterycz et al., 2010). With respect to ODRIs, the most important resistance mechanisms are those that confer tolerance to antibiofilm antibiotics (i.e. rifampicin for Gram-positive bacteria or fluoroquinolones for Gram-negative bacteria). In cases where no biofilm-active antibiotic is available, amputation or life-long antibiotic suppression therapy is often the only option (Moriarty et al., 2016).

For the above-mentioned reasons, the WHO invests and promotes research and development on AMR (WHO, 2015). While there are some new antibiotics in development, the numbers are insufficient to address the present needs and the financial return on investment discourages further development, particularly considering the potential restrictions on the use of any new antibiotics and the risk of rapid development of resistance. Therefore, scientists are focusing on other antimicrobial strategies and one of these is bacteriophage therapy.

\section{Bacteriophages as novel therapeutics}

\section{Advantages of bacteriophage therapy}

(Bacterio)phages are viruses that are highly specific, as they often infect only a subset of strains within a bacterial species. They infect bacteria by binding to receptors on the bacterial cell surface and injecting their genetic material into the cell. These receptors are strain-specific and can consist of proteins on the bacterial cell wall, teichoic acids, etc.. Then, phages can either hijack the bacterial metabolism, replicate intracellularly and, finally, lyse the host bacterium by which phage progeny are released (known as the 
lytic life cycle; Fig. 1) or enter a dormant state within the bacterial cell (known as the lysogenic life cycle). For this reason, with respect to phage therapy, where the goal is to eradicate the pathogenic bacteria, only strictly lytic phages are considered to be adequate. The majority (96\%) of all phages are tailed and belong to the order of the Caudovirales. There are three main families of tailed phages: the Myoviridae with contractile tails (25\%), the Siphoviridae with long, non-contractile tails (61\%) and the Podoviridae with short tails (14\%) (Ackermann and Wegrzyn, 2014). Staphylococcal phages used for phage therapy are virulent (strictly lytic) phages, mainly belonging to the family of Myoviridae or Podoviridae (Deghorain and Van Melderen, 2012). An example of a strictly lytic staphylococcal phage belonging to the Myoviridae is phage Remus (Vandersteegen et al., 2013), of which an electron microscopic image is displayed in Fig. 2.

Almost immediately after their discovery in the early 1900s, phages were applied as an antimicrobial therapy to combat bacterial infections (i.e. dysentery and cholera) in humans (Summers, 2001). However, due to the discovery of penicillin at the start of World War II, phage therapy was replaced with antibiotic treatment in most parts of the western world. In contrast, phage therapy continued to be applied within the Soviet Union and Eastern Europe (Abedon et al., 2011). To date, in countries including Georgia,
Poland and Russia, phage products remain directly available to the general public without prescription as the standard of care for bacterial infections. For instance, the Intesti phage cocktail from the Eliava Institute (Tbilisi, Georgia) targets about twenty different gastrointestinal pathogens (Zschach et al., 2015). Their Pyo bacteriophage cocktail, on the other hand, contains phages targeting Staphylococcus, Streptococcus, Pseudomonas, Proteus species and Escherichia coli (E. coli) and is routinely applied for various purulent skin or wound infections (Abedon et al., 2011).

Because of the emergence of antibiotic-resistant strains during the last decades, the therapeutic use of (strictly lytic) phages has seen a renewed interest in western medicine (Cisek et al., 2017). A dramatic, clinical example in which the power of phage therapy is demonstrated is the successful treatment of a 15-year-old post-transplant cystic fibrosis patient who suffered from a drug-resistant Mycobacterium infection and was treated palliatively with chronic antibiotics. The Mycobacterium infection was eradicated after long-term phage therapy using a cocktail of phages, one of which was engineered to optimise infection and kill bacteria (Dedrick et al., 2019). Indeed, phages have several important properties that contribute to their therapeutic potential. First, phages can selfamplify, which is an asset that contributes to their

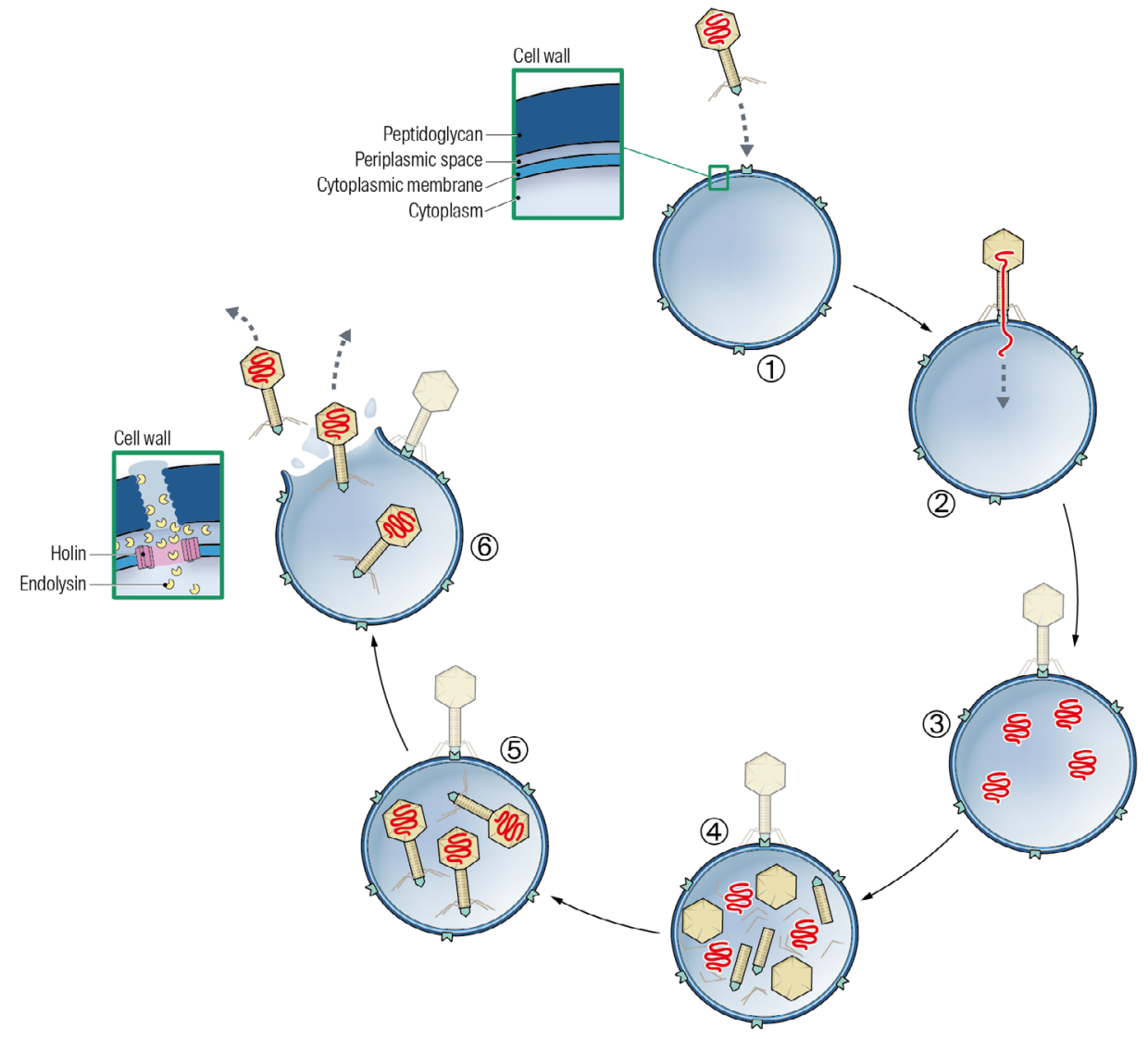

Fig. 1. The lytic infection cycle of bacteriophages. 1) A phage recognises a pattern on the bacterial cell wall and attaches; 2) after attachment to the cell wall, the phage injects its DNA; 3 ) the replication machinery of the bacteria is hijacked: the viral (phage) DNA is replicated; 4) the bacterial cell begins producing virion proteins; 5) phage proteins are assembled within the cell; 5) bacterial cell lysis is mediated by holin-endolysin interaction and phage progeny is released, being able to infect other bacteria. 
efficacy and distinguishes them from conventional antimicrobials (Kutter et al., 2010). Second, some phages display polysaccharide depolymerases on their tail structures, which can act as an adjuvant to phage infection by degrading the extracellular matrix of biofilm-associated bacteria (Pires et al., 2016). Third, phages are considered to be safe as human tissue and normal human bacterial flora are not negatively affected, which can be attributed to their high specificity (they often infect just a subset of strains within a single species) and quick inactivation and clearance once their host is no longer present (Abedon and Thomas-Abedon, 2010; Curtright and Abedon, 2011; Kutter et al., 2010). This also implies that for each new bacterial strain, a specific phage may need to be found (Payne and Jansen, 2003). Luckily, due to their abundant presence in nature, phages can be easily isolated and readily characterised (Chan et al., 2013). Finally, the modes of action of phages differ from those of antibiotics, so they are usually not affected by bacterial antibiotic-resistance mechanisms (Loc-Carrillo and Abedon, 2011), which is the main reason for the increased interest in phage therapy in parallel to the increase in antibiotic resistance seen in recent decades.

\section{Bacteriophage endolysins}

Based on the mechanism of action of lytic phages (Fig. 1), another potentially interesting antimicrobial strategy is the use of phage-derived proteins (Czaplewski et al., 2016). Endolysins, or phage lysins, are peptidoglycan hydrolases that are used by lytic phages towards the end of the lytic cycle to break down the peptidoglycan layer of the host bacterium so that the phage progeny can be released. Recombinant purified endolysin can be applied exogenously to eradicate susceptible Gram-positive bacteria, as reported in several in vitro and preclinical studies (Haddad Kashani et al., 2018). Currently, there is one endolysin (CF-301) that is being tested in human patients suffering from bacteraemia caused by S. aureus. Based on the results from previous trials, the FDA has recently approved a phase $3 \mathrm{RCT}$ to assess the efficacy and safety of this endolysin versus standard-of-care antibiotics (Web ref. 1). However, for Gram-negative infections, only few phage endolysins have the ability to pass the outer membrane and break down the peptidoglycan layer (Briers and Lavigne, 2015). In this regard, promising results were obtained with the engineered endolysin-based Artilysins, which are endolysins recombinantly fused to an outer membrane permeabilising peptide (Defraine et al., 2016; Schirmeier et al., 2018). Further progress in the (pre)clinical analysis of endolysins and Artilysins is expected in the upcoming years (Briers and Lavigne, 2015). To the authors' knowledge, these endolysins have not yet been applied in musculoskeletal infection settings. Therefore, the present review will focus on the treatment and prevention of ODRIs using bacteriophages.

\section{Pharmacology of bacteriophages}

Pharmacology, the science of drugs, can be subdivided into pharmacodynamics and pharmacokinetics. Both are to be extensively evaluated before an antimicrobial agent or any other drug becomes available for physicians to prescribe. Even though phage therapy is not a novel technique, evidence on its pharmacological profiles is rather limited (Ryan et al., 2011). This section summarises the available knowledge on pharmacodynamics and pharmacokinetics with respect to phages.

Pharmacodynamics is the study of the drug's influence on the organism, body or tissue. It entails the relationship between the drug's efficacy (e.g. bacterial eradication, duration of action, etc.) and toxicity (i.e. side effects). Unlike the metabolic degradation of certain antibiotics, the degradation of phage virions does not lead to toxic by-products, as phages mainly consist of protein and DNA. These phage constituents generally do not elicit immunological adverse reactions, as long as preparations are correctly purified and possible contaminants of the host bacteria such as endotoxins are eradicated

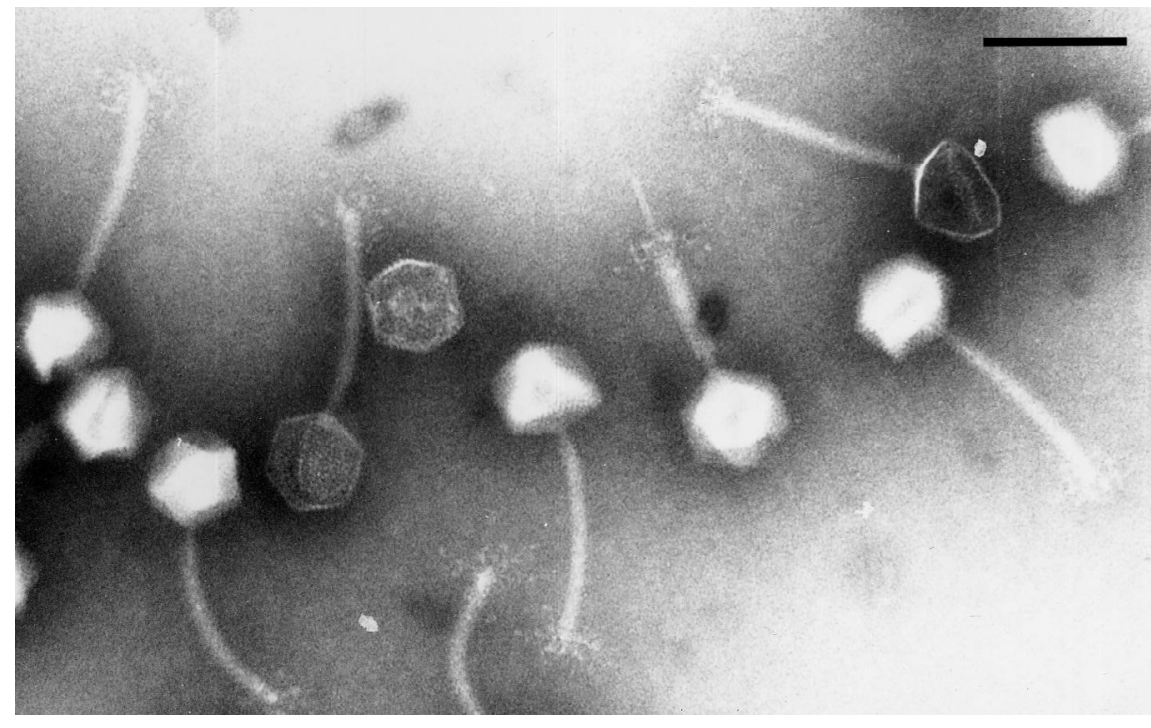

Fig.2. Transmission electron microscopic image of the staphylococcal phage Remus (Myoviridae) negatively stained with $2 \%(\mathrm{w} / \mathrm{v})$ potassium phosphotungstate (pH 7.0). Scale bar: $100 \mathrm{~nm}$. 
(Dufour et al., 2017; Loc-Carrillo and Abedon, 2011; Van Belleghem et al., 2017). The interaction of phages with the human immune system is further discussed below.

Phages display single-hit kinetics which implies that a single adsorption (or infection) of a phage to a bacterium is sufficient to mediate bacterial killing (Abedon and Thomas-Abedon, 2010). However, in clinical practice, where large numbers of bacteria are to be eradicated, a higher ratio of adsorbed phages to bacteria may be required. The exact concentration at which phage therapy shows optimal efficacy depends on several factors. First, it is important to know the difference between active and passive phage therapy. Primary adsorption, infection of bacteria and subsequent bacterial lysis is referred to as passive phage therapy. The secondary adsorption and infection of the phage progeny (i.e. the phages that are released after self-replication within the bacterial host) is referred to as active phage therapy (Abedon and Thomas-Abedon, 2010; Curtright and Abedon, 2011; Payne and Jansen, 2003). If the initially applied concentration of phages is high enough, then primary infection can eradicate a sufficient number of bacteria. Of course, this is the most optimal situation so that the therapy success does not depend on the ability of the phages to self-amplify. A general ruleof-thumb for phage therapy is to obtain and maintain a ratio of adsorbed phages to bacteria (or MOI) of 10 (Abedon and Thomas-Abedon, 2010). If for some reason it is expected that phages will have difficulty to penetrate their target bacteria or that they will have a high chance of early decay (e.g. by immunemediated neutralisation), it may be necessary to employ either multiple or continuous dosing or higher phage densities to obtain the same ratio. Active phage therapy can also reach the required ratio, but a sufficient number of bacteria should be present to give rise to a sufficient phage progeny to infect the residual bacteria (Abedon and Thomas-Abedon, 2010).

Pharmacokinetics studies the effects of the organism, body or tissue on the drug's activity and thereby on reaching and sustaining effective drug concentrations at the target sites. Specifically, for phage therapy, the following stages should be considered in the pharmacokinetic profile: absorption, distribution, penetration, adsorption, infection, lysis and phage release (Abedon and Thomas-Abedon, 2010). Absorption and distribution are generally not of importance for local application of phage therapy, which is often required for an ODRI (Onsea et al., 2019; Ryan et al., 2011). For systemic therapy, the persistence of phages depends on the efficacy of the reticuloendothelial system clearance and potentially on the induction of phage-specific antibodies that may cause phage inactivation (Maciejewska et al., 2018). As discussed above, this may be tackled by applying multiple doses and using phage cocktails to prevent cross-linking of anti-phage antibodies (Curtright and Abedon, 2011; Maciejewska et al.,
2018). Penetration refers to the ability of phages to penetrate a biofilm (e.g. mediated by extracellular polysaccharide depolymerase enzymes). After penetration, the phage can adhere to the surface of the host bacteria and subsequently infect and lyse it, which are referred to as adsorption, infection and lysis, respectively. In the case of an active therapy, phage release follows bacterial lysis (Abedon and Thomas-Abedon, 2010).

In general, it should be clear that the main challenge remains the understanding of the dynamic of phage titers in vivo. The involved parameters, including bacterial and phage microbiological traits and individual immunological response, are all interdependent and incompletely understood at the present time.

\section{Interactions with the human immune system}

The clearance of phages by the immune system may affect the efficacy of phage therapy (Dabrowska and Abedon, 2019; Maciejewska et al., 2018). Since phages are encountered on a daily basis (e.g. through various foods), low titers of phage-specific antibodies are common in patients, but titers may increase during phage therapy. The induction of the innate immune system, that clears phages through phagocytosis (i.e. the reticuloendothelial system), as well as of the adaptive immune system by the production of phage-neutralising antibodies, has been associated with early depletion of phages and subsequent impairment of efficacy (Cisek et al., 2017; Malik et al., 2017). For oral and topical applications, this seems to be less of an issue when compared to systemic application. However, it might still be necessary to compensate for this phenomenon by repeating phage administration, increasing phage concentration or using different phages or a phage cocktail (Cisek et al., 2017; Hodyra-Stefaniak et al., 2015; Maciejewska et al., 2018; Malik et al., 2017). Controversially, there are recent studies that do acknowledge the interaction between phages and the human immune system, but state that this does not impact the outcome of phage therapy (Lusiak-Szelachowska et al., 2014; Lusiak-Szelachowska et al., 2017; Zaczek et al., 2016). Furthermore, the stimulation of the immune system by phages may even be required to obtain a good treatment outcome (Roach et al., 2017). Further exploration of this topic is needed to elucidate the role of the human immune response in phage therapy.

Although no serious clinical immunological complications of phage therapy have been reported to date (Maciejewska et al., 2018), an issue that may arise is that of an indirect immunogenicity by means of cell lysis. When looking at the mechanism of action of lytic phages as well as that of some antibiotics such as penicillins, bacteria are lysed and bacterial cell wall components are released. In clinical cases where patients are expected to suffer from highinoculum Gram-negative infections, this endotoxin release might lead to clinical deterioration and septic shock (Abedon and Thomas-Abedon, 2010; Dufour et 
al., 2017; Goodridge, 2010). However, the relevance of this phage-related endotoxin-release depends on the clinical situation of the patient. An endotoxinrelease can also be caused by antibiotics that target the bacterial cell wall (i.e. $\beta$-lactam antibiotics) and this is generally due to systemic infections that are already life-threatening (Abedon and Thomas-Abedon, 2010; Dufour et al., 2017). It should be clear that the general interaction between bacteria, phages and the human immune system represents an intertwined triangle which remains difficult to model/predict accurately (Van Belleghem et al., 2018).

\section{Resistance patterns}

Bacteria and phages have co-evolved for billions of years. Phage-resistant strains arise and protect the bacterial lineage while on the other side of the spectrum counter-resistant phages arise that can again threaten these strains (Labrie et al., 2010). This co-evolution seems to be an important driver of ecological and evolutionary processes in microbial communities (Labrie et al., 2010; Rohde et al., 2018a; Torres-Barcelo, 2018). The frequency at which phage resistance complicates phage therapy is not clear, although Rohde et al. (2018a) reported resistance rates varying from $17 \%$ (to Staphylococcus phages) to $85 \%$ (to E. coli phages). Bacterial resistance mechanisms can be developed against a phage at almost every stage of its life cycle. Phage resistance mechanisms can be classified into prevention of phage adsorption, prevention of phage DNA entry, cutting of phage nucleic acids and abortive infection systems (Labrie et al., 2010; Maciejewska et al., 2018). The most common form of phage resistance is prevention of phage adsorption by point mutations and/or changes in the expression of receptor-encoding genes, thereby adapting the structure or conformation of bacterial cell surface receptors (Maciejewska et al., 2018). It is interesting that phage resistance through these mechanisms can emerge rapidly, but often goes with a cost of losing bacterial virulence (Levin and Bull, 2004; Maciejewska et al., 2018; Rohde et al., 2018a). That is, the bacterial surface molecules that are involved in phage-bacteria interaction often consist of surface proteins, surface glycans and glycoconjugates such as capsules and lipopolysaccharides. A change in these components could result in reduced virulence and renewed susceptibility to the host's immune system (Levin and Bull, 2004; Maciejewska et al., 2018). Apart from changing the surface receptors, resistance can also be achieved by the production of extracellular matrix, an important constituent of biofilm, which provides a physical barrier between the phages and their receptors. Some phages have evolved to recognise the polymers that comprise the extracellular matrix and degrade them. Other bacteria prevent phage DNA entry by using proteins [i.e. superinfection exclusion (Sie) systems] (Labrie et al., 2010; Maciejewska et al., 2018). Recently, a lot of research has been done on resistance mechanisms that interfere with phage DNA introduction in bacteria. Important resistance mechanisms are restrictionmodification systems that degrade phage DNA, while the bacterial host DNA is protected (Ofir et al., 2018). Although the molecular mechanisms are still unclear, the CRISPR/Cas system has been found to function as a bacterial acquired immune system that memorises viral genetic material to target future infection attempts (Labrie et al., 2010). The phage exclusion system (BREX) and the prokaryotic Argonaute variants were discovered more recently to act as a barrier for the uptake and replication of foreign DNA (Goldfarb et al., 2015; Swarts et al., 2014). The last resort of bacterial resistance mechanisms is an abortive infection system. This system leads to the death of the infected host bacteria, thereby preventing phage amplification and further infection of other bacteria (Labrie et al., 2010). An important property of the continuous arms race between phages and bacteria is the emergence of phage strategies to counteract or circumvent these resistance mechanisms (Bondy-Denomy et al., 2013). For instance, phages can modify the course of their life cycle (e.g. by adjusting burst size, lysis time, etc.) (Torres-Barcelo, 2018) and can encode protein inhibitors of CRISPR-Cas systems (i.e. anti-CRISPRs) (Stanley et al., 2019). Furthermore, mutations in phage receptor binding proteins can arise and phages can recombine with other viruses (Torres-Barcelo, 2018).

The emergence of phage-resistant strains is a natural consequence of co-evolution. Before setting up a phage therapy regimen, measures should be taken to compensate for resistance. Phage cocktails should be applied that cover a broad host range and target highly conserved structures essential for bacterial survival or virulence (Rohde et al., 2018a).

\section{Pre-clinical evidence}

\section{In vitro studies}

The most prevalent Gram-positive bacterial species in ODRIs are S. aureus (33-43\%), S. epidermidis (18$40 \%)$ and Enterococcus species (2.5-15\%, mainly E. faecalis), while Gram-negative bacilli, including E. coli and $P$. aeruginosa, are less frequently isolated (4-7\%) (Arciola et al., 2018; Barros et al., 2019; Cremet et al., 2012; Landraud et al., 2013; Tande and Patel, 2014). In vitro studies proving the efficacy of phages against strains isolated from ODRIs are not that numerous.

In 2014, Kaur et al. (2014) reported that phage MR-5 could kill S. aureus in vitro on Kirschner wires in the presence of linezolid. Coatings that combined both MR-5 and antibiotics (impregnated in hydrogel) prevented implant colonisation with a maximum reduction in bacterial adherence of about $4 \log _{10}$ units after $48 \mathrm{~h}$. This result was superior when compared to coatings including only MR-5 or linezolid. Moreover, the emergence of resistant mutants was negligible in the presence of both agents, proving the potential of 
phage-mediated therapy in these types of infections (Kaur et al., 2014).

Morris et al. (2019) screened thirty S. aureus strains isolated from patients undergoing total knee or hip arthroplasty for their susceptibility to a set of $31 \mathrm{~S}$. aureus-specific phages. Five of these demonstrated activity against more than $90 \%$ of the tested strains and were combined in a StaPhage cocktail. Then, this cocktail was assessed for its bactericidal activity towards both planktonic and biofilm-associated S. aureus strains. Planktonic growth was reduced in 8 h-cultures by more than $98 \%$ after treatment with StaPhage, compared to untreated samples. Moreover, viable cells within 48 h-old biofilms, formed on three-dimensional-printed porous titanium scaffolds, were only slightly but significantly reduced for one of the tested strains (from $6.8 \log _{10}$ to $6.2 \log _{10}$ ) after a $48 \mathrm{~h}$ treatment with the StaPhage cocktail. On the other hand, the cefazolin control, frequently used as a prophylactic antibiotic, did not show any reduction (100× the minimal inhibitory concentration of cefazolin was applied). The other tested strain did not display any reduction after treatment. These data suggested that, at least for the mentioned phage, biofilms can not only display greater resistance to antibiotic agents but also to phages. The authors concluded that not only the administered concentration, frequency of dosing and administration route, but also the use of customised cocktails to a given patient-specific strain are critical for further in vivo studies (Morris et al., 2019).

Barros et al. (2019) reported the isolation of nineteen clinical strains, among which six $S$. aureus, seven E. faecalis and two E. coli strains, all isolated from ODRIs in a Portuguese hospital and resistant to at least one antibiotic in three or more antimicrobial classes. The authors examined the in vitro efficacy of several phages, of which phage LM12 was able to lyse $91 \%$ of all tested S. aureus strains, phage LM99 was able to lyse $64 \%$ of all tested E. faecalis strains and phage JB75 was able to lyse $55 \%$ of all tested $E$. coli strains. In vitro, the three lytic phages presented good therapeutic potential, displaying rapid infection cycles with large burst sizes, a high specificity and good tolerance to thermal and $\mathrm{pH}$ changes. Based on their data, the authors concluded that phages LM12, LM99 and JB75 could be suitable to treat ODRIs.

While relatively few in vitro studies have described phage activity against ODRI-associated strains, a far larger number of studies have investigated the ability of phages to inhibit biofilm formation. For example, phage $\mathrm{K}$ was shown to prevent biofilm formation of $S$. aureus grown on silicone disks for $24 \mathrm{~h}$ (Lungren et al., 2013). Addition of $2 \times 10^{8} \mathrm{PFU}$ phage $\mathrm{K}$ for $24 \mathrm{~h}$ resulted in a significant reduction of average $S$. aureus counts from $6.3 \times 10^{5} \mathrm{CFU}$ to $6.7 \times 10^{1} \mathrm{CFU}$, demonstrating the enormous in vitro potential of this phage. Another study by Alves et al. (2014) demonstrated that a combination of phage K and DRA88 (a broad host range phage) at an MOI of 10 also effectively reduced $S$. aureus biofilm biomass
( $48 \mathrm{~h}$ old biofilms) within $48 \mathrm{~h}$. A study by Yuan et al. (2019) revealed that the lytic phage vB_PaeM_LS1 showed a high potential impact upon the prevention of biofilm formation by $P$. aeruginosa. By scanning electron microscopy, they showed that phage LS1 was able to disrupt a 48 h-old biofilm (grown under static conditions) in $8 \mathrm{~h}$. Counting of bacterial colonies indicated a reduction of about $99.7 \%$ when compared to the control biofilm. At $24 \mathrm{~h}$, regrowth was observed, due to the emergence of phage-resistant colonies.

\section{In vivo studies}

S. aureus is the most often applied Gram-positive pathogen in in vivo studies (Matsuzaki et al., 2014). $P$. aeruginosa is the most often applied Gram-negative pathogen. Published studies primarily focus on pulmonary infections followed by gastrointestinal infections, septicaemia, urinary tract infections, wound infections and meningitis (Matsuzaki et al., 2014).

Regarding ODRIs, there are few studies available (Table 1). Kaur et al. (2016) investigated the benefits of the synergism between antibiotics and phages for the prevention of ODRIs caused by MRSA. A coated Kirschner wire was implanted in the mouse femur and the joint space was inoculated with MRSA. Compared to single coated or naked implants, the use of a dual coated implant was more effective in reducing bacterial adherence and, therefore, protecting the implant from infection (Kaur et al., 2016). Wroe et al. (2019) evaluated the application of an injectable phage-loaded hydrogel as a prevention measure for FRIs. The hydrogel was loaded with phages and bacteria for delivery within a perforated polyimide sleeve, which was fitted over the segmental defect in the murine radius. The phage-loaded hydrogel succeeded in significantly reducing the bacterial load recovered after euthanasia. However, as this was a proof-of-concept study, the phage-treated group was only compared to the positive control group, which received no preventive antibacterial treatment (i.e. no antibiotic prophylaxis, which is the standard of care in this setting) (Wroe et al., 2019).

Regarding the effect of phages in a therapy setting for ODRIs, few studies are available. In the study by Yilmaz et al. (2013), phages were applied locally in a rat model of PJI. The tibiae of the rats were inoculated with MRSA or $P$. aeruginosa and a plastic intravenous catheter with an established biofilm, caused by the respective pathogens, was placed inside the intramedullary canal. Regardless of the pathogen that was applied, the best treatment results were obtained with a combination of antibiotics and phages. In the MRSA group, biofilm dispersion could only be achieved with a combination treatment (Yilmaz et al., 2013). It should be noted that the study set up was not entirely representative of an ODRI as the authors used a plastic catheter sheath with an already established biofilm as an implant rather than metallic fracture fixation materials or prostheses (Moojen, 2013). Kishor et al. (2016) investigated the 
Table 1. In vivo studies investigating the application of bacteriophages for the prevention or treatment of ODRIs. PJI: prosthetic joint infection; FRI: fracture-related infection; HPMC: hydroxypropyl methylcellulose; BMP: bone morphogenetic protein; CRISPR: clustered regularly interspaced short palindromic repeats.

\begin{tabular}{|c|c|c|c|c|c|}
\hline \multicolumn{6}{|c|}{ Prevention studies } \\
\hline Study & Model & Study design & Pathogen & Phage & Outcome \\
\hline $\begin{array}{l}\text { Kaur et } \\
\text { al., } 2016\end{array}$ & $\begin{array}{c}\text { Murine } \\
\text { model of PJI }\end{array}$ & $\begin{array}{c}\text { Coated implant } \\
5 \text { groups: } \\
\text { - } \quad \text { coated with phage in } \\
\text { HPMC } \\
\text { - } \quad \text { coated with antibiotic in } \\
\text { HPMC } \\
\text { - coated with phage and } \\
\text { antibiotic in HPMC } \\
\text { - } \quad \text { coated with HPMC } \\
\text { negative control (naked } \\
\text { implant) }\end{array}$ & MRSA & MR-5 & $\begin{array}{l}\text { Dual coating } \\
\text { resulted in } \\
\text { maximum reduction } \\
\text { in bacterial load, } \\
\text { associated joint } \\
\text { inflammation and } \\
\text { faster functional } \\
\text { recovery of the limb }\end{array}$ \\
\hline $\begin{array}{l}\text { Wroe et } \\
\text { al., } 2019\end{array}$ & $\begin{array}{c}\text { Murine } \\
\text { model of FRI }\end{array}$ & $\begin{array}{c}2 \text { groups: } \\
\text { - } \quad \text { BMP-2 loaded hydrogel } \\
\text { with phage cocktail } \\
\text { - } \quad \text { positive control (empty } \\
\text { hydrogel) } \\
\end{array}$ & $\begin{array}{c}P . \\
\text { aeruginosa }\end{array}$ & $\begin{array}{l}\text { ФPaer4, } \\
\text { ФPaer14, } \\
\text { ФPaer22, } \\
\text { ФW2005A }\end{array}$ & $\begin{array}{l}\text { Significant decrease } \\
\text { in bacterial load in } \\
\text { phage-treated group }\end{array}$ \\
\hline \multicolumn{6}{|c|}{ Treatment studies } \\
\hline $\begin{array}{l}\text { Yilmaz et } \\
\text { al., } 2013\end{array}$ & $\begin{array}{l}\text { Rat model } \\
\text { of implant- } \\
\text { associated } \\
\text { osteomyelitis }\end{array}$ & $\begin{array}{c}4 \text { groups: } \\
\text { - phage } \\
\text { - antibiotics } \\
\text { - phage + antibiotics } \\
\text { - negative control }\end{array}$ & $\begin{array}{c}\text { MRSA/ } \\
P . \\
\text { aeruginosa }\end{array}$ & $\begin{array}{l}\text { Sb-1/ PAT14 } \\
\text { Local } \\
\text { injection } \\
\text { on three } \\
\text { consecutive } \\
\text { days } \\
\end{array}$ & $\begin{array}{l}\text { Combination } \\
\text { therapy resulted in } \\
\text { the highest bacterial } \\
\text { killing rate across all } \\
\text { groups }\end{array}$ \\
\hline $\begin{array}{l}\text { Kishor et } \\
\text { al., } 2016\end{array}$ & $\begin{array}{c}\text { Rabbit } \\
\text { model of } \\
\text { osteomyelitis }\end{array}$ & $\begin{array}{c}3 \text { groups: } \\
\text { - acute osteomyelitis: phage } \\
\text { therapy start after } 16 \mathrm{~d} \\
\text { - chronic osteomyelitis: } \\
\text { phage therapy start after } 6 \\
\text { weeks } \\
\text { - positive control }\end{array}$ & MRSA & $\begin{array}{l}\text { Cocktail with } \\
\text { SA-BHU1, } \\
\text { SA-BHU2, } \\
\text { SA-BHU15, } \\
\text { SA-BHU21, } \\
\text { SA-BHU37, } \\
\text { SA-BHU47 } \\
\end{array}$ & $\begin{array}{l}\text { Phage therapy } \\
\text { succeeded in } \\
\text { eradicating the } \\
\text { infection }\end{array}$ \\
\hline $\begin{array}{l}\text { Cobb et } \\
\text { al., } 2019\end{array}$ & $\begin{array}{l}\text { Rat model } \\
\text { of implant- } \\
\text { associated } \\
\text { osteomyelitis } \\
\text { and soft } \\
\text { tissue } \\
\text { infection }\end{array}$ & $\begin{array}{c}\text { - } 4 \text { groups: } \\
\text { - alginate hydrogel loaded } \\
\text { with phage } \\
\text { - alginate hydrogel loaded } \\
\text { with phosphomycin } \\
\text { - alginate hydrogel } \\
\text { loaded with phage and } \\
\text { phosphomycin } \\
\text { - positive control (empty } \\
\text { alginate hydrogel) }\end{array}$ & S. aureus & $\begin{array}{c}\text { ФSaBov- } \\
\text { CRISPR/Cas9 }\end{array}$ & $\begin{array}{l}\text { Phage therapy and } \\
\text { the combination of } \\
\text { phage therapy and } \\
\text { antibiotics resulted } \\
\text { in a significant } \\
\text { reduction in the } \\
\text { bacterial load in the } \\
\text { soft tissue, not in } \\
\text { bone. A high dose } \\
\text { of phosphomycin } \\
\text { ( } 3 \text { g) could reduce } \\
\text { the bacterial load in } \\
\text { bone }\end{array}$ \\
\hline
\end{tabular}

efficacy of phage therapy for the treatment of OM (i.e. no implant) of the femur caused by MRSA in a rabbit model. A distinction was made between acute and chronic OM. That is, for the acute group, treatment was started $16 \mathrm{~d}$ after inoculation with a total of four doses $48 \mathrm{~h}$ apart from each other, whereas treatment for the chronic group was only started after 6 weeks. In both phage-treated groups, a total of four doses were given locally, $48 \mathrm{~h}$ apart from each other. Phage monotherapy was successful in eradicating MRSA in both the acute and chronic OM setting (Kishor et al., 2016). Finally, Cobb et al. (2019) studied the effects of a CRISPR-Cas9-modified S. aureus bacteriophage in a rat model of OM of the femur and surrounding soft tissue infection. A contaminated orthopaedic screw was placed in the femur and left for $7 \mathrm{~d}$, after which the screw was removed and the therapeutics injected (i.e. antibiotics and/or phages in an alginate hydrogel) into the defect space. After $24 \mathrm{~h}$, all animals were euthanised and treatment effects evaluated. 
Both phages and antibiotics, in combination or alone, significantly reduced the bacterial load in the soft tissue but not in bone. Only an extremely high dose of phosphomycin (i.e. $3 \mathrm{~g}$ ) was able to significantly reduce the bacterial load in bone. The authors attributed this to the fact that the phage titer delivered through the alginate hydrogel was limited to $10^{7} \mathrm{PFU} / \mathrm{mL}$. Also, no surgical treatment to reduce the bacterial load, which is standard clinical practice, was performed concomitantly (i.e. debridement and irrigation) (Cobb et al., 2019).

To date, these are the only preclinical in vivo studies that have assessed the efficacy of phage therapy regarding ODRIs. These studies have highlighted the potential of the approach, under controlled conditions. However, there are several areas where these studies may have limitations in relation to eventual clinical implementation. These studies included only monomicrobial infections caused by S. aureus (i.e. MRSA) or P. aeruginosa. As other pathogens such as coagulase-negative Staphylococci (e.g. S. epidermidis) and Gram-negative bacteria (e.g. Enterobacter species) are also commonly isolated, future preclinical models should focus on these pathogens as well (Vanvelk et al., 2018). Furthermore, it has become a widely held view that most, if not all, biofilms in nature are polymicrobial (Gabrilska and Rumbaugh, 2015; Wolcott et al., 2013). Indeed, a preclinical model assessing the impact of phage therapy upon polymicrobial ODRIs may be more relevant to the human equivalent, but the development of such models is a challenge (Gabrilska and Rumbaugh, 2015; Vanvelk et al., 2018). Therefore, future research on this topic is required to develop more realistic animal models for ODRIs.

\section{Carriers}

The administration of local antimicrobial agents for the treatment of musculoskeletal infections offers the prospect of improved therapeutic efficacy over that achievable by systemic delivery alone (Metsemakers et al., 2019). That is, the local application of antimicrobials is not impacted by possible vascular impairment (i.e. open fractures), which is a frequently encountered hurdle in the treatment of these infections (Metsemakers et al., 2016). Furthermore, by directly delivering the antimicrobial to the infected site, the pharmacokinetic properties of systemic drug delivery, which can decrease the drug bioavailability, are bypassed (Ryan et al., 2011). If high systemic doses are required to obtain an adequate local concentration, a local approach also reduces the risk of systemic toxicity.

The application of local antibiotics is currently gaining interest and several products are already licensed and approved for human use (Metsemakers et al., 2019; ter Boo et al., 2015). Regarding the local delivery of phages, clinical trials generally use simple phage suspensions directly applied to the wound and without any formulation, which often require repeated dosing. Especially for musculoskeletal infections, this approach is cumbersome and increases the burden on patients as an external draining system is required to apply phages in multiple doses for a period of up to $10 \mathrm{~d}$ postoperatively (Fig. 3) (Onsea et al., 2019). Hence, the encapsulation of phages into a sustained release system, that can be applied once intraoperatively, would constitute an ideal situation (Malik et al., 2017). Phages are essentially protein structures, which implies that they are susceptible to all environmental changes that denature protein, such as acidic $\mathrm{pH}$, high temperatures, exposure to organic solvents (e.g. disinfectants) and mechanical stresses (Malik et al., 2017; Merabishvili et al., 2017). Therefore, when designing a carrier for phage therapy, these factors should be considered.

Several studies exist on the topical administration of phages using different carriers, such as slowrelease biopolymers (Jikia et al., 2005; Markoishvili et al., 2002), bandages (Jault et al., 2018), creams (Brown et al., 2016) or hydrogels (Kumari et al., 2010). Indications for topical administrations range from venous stasis ulcers to burn wounds and other poorly healing wounds that do not respond to conventional therapy. These studies underline the fact that the efficacy of phage therapy is concentration dependent.

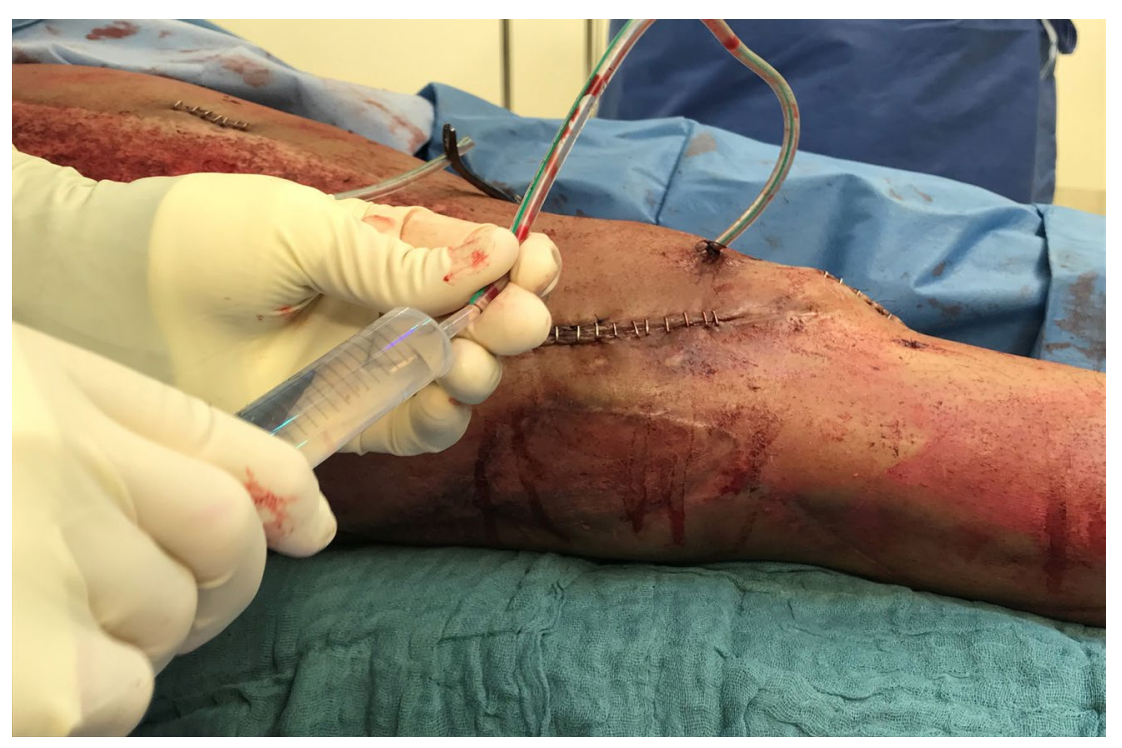

Fig. 3. Local phage application for an ODRI through an external draining system. Courtesy of W-J. Metsemakers and J. Onsea, Department of Trauma Surgery, University Hospitals Leuven, Belgium. 
Low-titre phage administration is unlikely to be successful, which again underlines the importance of phage stability in each formulation (Jault et al., 2018; Ryan et al., 2011; Wroe et al., 2019).

In the field of ODRIs, evidence on the optimal carrier for phage therapy is currently scarce. Meurice et al. (2012) investigated the application of ceramics (beta-tricalcium phosphate and hydroxyapatite) loaded with phages for the prevention of infection with E. coli in vitro (Meurice et al., 2012). The ceramic porosity is an essential factor for the impregnation of antimicrobials, which accelerates the kinetics of their release. Indeed, microporosity increases the surface area of the material so that more phages are retained. The authors concluded that, with the right porosity and composition, phage-loaded ceramics exhibit an antibacterial activity that is close to that of antibioticloaded ceramics. Even after $6 \mathrm{~d}$, there were sufficient phages to eliminate bacterial cells (Meurice et al., 2012). Kaur et al. (2016) developed a biodegradable drug-delivery system in the form of a coating for the prevention of ODRIs with MRSA. The coating consisted of a polymer (HPMC) that was mixed with linezolid and phages active against the specific strain of MRSA. Compared to naked implants, the coated counterparts with a combination of phage and antibiotic was associated with a maximum reduction in bacterial adherence to the implant. Furthermore, a higher concentration of the polymer was shown to have the most appropriate release kinetics (Kaur et al., 2014). This coating was further investigated in an in vivo experiment, which was detailed in the previous section (Table 1) (Kaur et al., 2016). Wroe et al. (2019) (Table 1) developed an injectable polyethyleneglycol-based hydrogel loaded with phages directed against $P$. aeruginosa. The authors showed that phages remain active after encapsulation and their release can be regulated by gel degradation in vivo. Finally, Cobb et al. (2019) studied the effects of an alginate hydrogel loaded with phage and/or antibiotics for the treatment of $\mathrm{OM}$ in a rat model. The in vitro biofilm experiments performed showed promising results. However, in the in vivo rat model, the treatment could reduce the bacterial burden in soft tissue, but not in bone. The authors attributed this to the small volume that could be applied into the small defect size and the thick consistency of the phage solution, which limited the concentration that could be prepared in the phage-loaded alginate hydrogel in the treatment setting (Cobb et al., 2019) (Table 1).

Although these studies show promising results with the carriers that were used, further research is needed in the field of phage formulation, thereby paying extra attention to phage stability.

\section{Clinical evidence}

Phage therapy is not a novel concept but has been applied since the start of the $20^{\text {th }}$ century. However, with the advent of antibiotics, it has lost ground in the western world, while research and development of phage therapy continued to thrive within the former Soviet Union and Eastern Europe (Abedon et al., 2011). Phage therapy research of that era was mostly published in languages other than English, which attributed even more to the western scepticism and subsequent fading interest in the application of phages to combat infections. Table 2 presents the clinical studies focusing on musculoskeletal infections, including ODRIs. All the cases included in these studies were diagnosed with therapy-resistant musculoskeletal infections.

The most extensive studies on phage therapy were performed in the former Soviet Union and more specifically in the Eliava Institute in Tbilisi, Georgia, where its clinical use and research remained strong even after the advent of antibiotics (Kutateladze and Adamia, 2008). One of the main indications for phage therapy in the Eliava Institute is OM (Kutateladze and Adamia, 2010). In the 1970's, phage therapy trials were conducted assessing the therapeutic effectiveness of their custom-made staphylococcal phage preparation against different infectious diseases, including $\mathrm{OM}$ and septic arthritis. In one of these trials 120 patients were included. Regardless of the therapy applied (antibiotics only, phage monotherapy or combination therapy), a $100 \%$ healing rate was reported (Kutateladze and Adamia, 2010). The added value of this trial is difficult to interpret as there are no (English) data available on population characteristics and patients in the antibiotics-only group recovered fully as well. Furthermore, the phage monotherapy group only consisted of nine patients and in the combination group the antibiotic therapy itself could have influenced the results.

Regarding musculoskeletal infections, one case series was reported by a French group in 1979. They treated seven patients with chronic infections unresponsive to conventional antimicrobial therapy. Five patients were treated successfully with phage therapy, with the follow-up period ranging between 13 and 18 months. Phages were applied locally (through a draining system or topically) after debridement of the wound. Although one patient with a spinal infection showed improvement as one of the causative pathogens (i.e. S. aureus) could be eradicated, the $P$. aeruginosa infection persisted. The authors reported a single treatment failure (Lang et al., 1979).

In Poland, Slopek et al. (1987) provided an overview of 550 cases treated with phages between 1981 and 1986, with success rates of $90 \%$ in patients with "pyogenic arthritis and myositis", "osteomyelitis of long bones" and "osteitis of long bones after fracture". Phages were administered locally and orally in these cases, no further treatment details were reported (e.g. treatment duration, dosage, formulation, etc.) (Slopek et al., 1987). In a subsequent case series from the same centre, similar success rates were reported (Weber-Dabrowska et al., 2000). 
Table 2. Human clinical studies on phage therapy for musculoskeletal infections. PJI: prosthetic joint infection; OM: osteomyelitis; FRI: fracture-related infection.

\begin{tabular}{|c|c|c|c|c|}
\hline Reference & $\begin{array}{l}\text { Sample } \\
\text { size }\end{array}$ & $\begin{array}{c}\text { Patient } \\
\text { characteristics }\end{array}$ & Intervention & Outcome \\
\hline $\begin{array}{c}\text { Lang et al., } \\
1979\end{array}$ & 7 & $\begin{array}{l}\text { PJI }(n=2) \\
\text { OM }(n=1) \\
\text { Septic arthritis } \\
\quad(n=1) \\
\text { Spinal infection } \\
\quad(n=1) \\
\text { FRI }(n=2)\end{array}$ & $\begin{array}{l}\text { Phages adapted to isolated strains } \\
\text { Administration either topical or } \\
\text { by injection through a draining } \\
\text { system. Some cases received } \\
\text { combination treatment with } \\
\text { antibiotics }\end{array}$ & $\begin{array}{l}\quad 5 / 7 \text { treated } \\
\text { Recurrence of spinal } \\
\text { infection and one FRI }\end{array}$ \\
\hline $\begin{array}{l}\text { Kutateladze } \\
\text { and } \\
\text { Adamia, } \\
2010\end{array}$ & 120 & $\begin{array}{l}\text { Patients with } \\
\text { staphylococcal } \\
\text { OM or arthritis }\end{array}$ & $\begin{array}{c}\text { Three groups: } \\
\text { - antibiotics }(n=60) \\
\text { - phage monotherapy }(n=9) \\
\text { - phage }+ \text { antibiotics }(n=51) \\
\text { Administration of Eliava } \\
\text { staphylococcal phage preparation } \\
\text { topically or intravenously }\end{array}$ & $\begin{array}{c}100 \% \text { success rate in } \\
\text { all groups }\end{array}$ \\
\hline $\begin{array}{c}\text { Slopek et al., } \\
1987\end{array}$ & 100 & $\begin{array}{l}\text { Purulent arthritis } \\
\text { and myositis } \\
\quad(n=19) \\
\text { OM of the long } \\
\text { bones }(n=40) \\
\text { FRI }(n=41)\end{array}$ & $\begin{array}{l}\text { Administration locally and/or } \\
\text { orally } \\
\text { Some cases received combination } \\
\text { treatment with antibiotics }\end{array}$ & $\begin{array}{c}\text { Success rates: } \\
\text { - purulent arthritis and } \\
\text { myositis: } 89.5 \% \\
\text { - OM of the long } \\
\text { bones: } 95 \% \\
\text { - FRI: } 90.2 \%\end{array}$ \\
\hline $\begin{array}{l}\text { Weber- } \\
\text { Dabrowska } \\
\text { et al., } 2000\end{array}$ & 81 & $\begin{array}{l}\text { OM of the long } \\
\text { bones }(n=40) \\
\text { FRI }(n=41)\end{array}$ & $\begin{array}{l}\text { Administration locally and/or } \\
\text { orally } \\
\text { Unclear if some patients received } \\
\text { combination treatment with } \\
\text { antibiotics }\end{array}$ & $\begin{array}{c}\text { Success rates: } \\
\text { OM of the long bones: } \\
95 \% \\
\text { FRI } 60 \%\end{array}$ \\
\hline $\begin{array}{l}\text { Vogt et al., } \\
2017\end{array}$ & 1 & $\mathrm{OM}$ & $\begin{array}{l}\text { Repeated dosing of phage cocktail } \\
\text { Pyo bacteriophage through } \\
\text { draining system, in combination } \\
\text { with antibiotic therapy }\end{array}$ & $\begin{array}{c}\text { Eradication of the } \\
\text { infection }\end{array}$ \\
\hline $\begin{array}{l}\text { Ferry et al., } \\
2018 \mathrm{a}\end{array}$ & 1 & $\begin{array}{c}\mathrm{OM} \\
\text { (post-radiation) }\end{array}$ & $\begin{array}{l}\text { Application of customised phage } \\
\text { cocktail every } 3 \mathrm{~d} \text {, in combination } \\
\text { with intravenous antibiotic therapy }\end{array}$ & $\begin{array}{l}\text { Patient died } 45 \mathrm{~d} \\
\text { after treatment due to } \\
\text { cancer progression }\end{array}$ \\
\hline $\begin{array}{l}\text { Ferry et al., } \\
2018 b\end{array}$ & 1 & PJI & $\begin{array}{l}\text { Single intraoperative injection of } \\
\text { a customised phage cocktail in } \\
\text { combination with intravenous } \\
\text { antibiotic therapy }\end{array}$ & $\begin{array}{c}\text { Eradication of the } \\
\text { infection }\end{array}$ \\
\hline $\begin{array}{c}\text { Nir-Paz et } \\
\text { al., } 2019\end{array}$ & 1 & FRI & $\begin{array}{c}\text { Intravenous repeated } \\
\text { administration of customised } \\
\text { phage cocktail, in combination } \\
\text { with intravenous antibiotic therapy }\end{array}$ & $\begin{array}{l}\text { Eradication of the } \\
\text { infection } \\
\text { (after two phage } \\
\text { therapy regimens) }\end{array}$ \\
\hline $\begin{array}{l}\text { Tkhilaishvili } \\
\text { et al., } 2019\end{array}$ & 1 & PJI & $\begin{array}{c}\text { Repeated dosing of customised } \\
\text { phage cocktail, in combination } \\
\text { with intravenous antibiotic therapy }\end{array}$ & $\begin{array}{c}\text { Eradication of the } \\
\text { infection }\end{array}$ \\
\hline $\begin{array}{c}\text { Onsea et al., } \\
2019\end{array}$ & 4 & $\mathrm{OM}$ & $\begin{array}{l}\text { Repeated dosing of BFC1 cocktail } \\
\text { or Pyo bacteriophage cocktail in } \\
\text { combination with intravenous } \\
\text { antibiotic therapy }\end{array}$ & $\begin{array}{l}\text { Eradication of the } \\
\text { infection in all cases }\end{array}$ \\
\hline
\end{tabular}


Although the above-mentioned studies showed promising results regarding the implementation of phage therapy in musculoskeletal infections, these results should be interpreted with caution. The methodology of these earlier trials was not in accordance to GCP guidelines as known today. They included reports on heterogeneous patient populations [different causative pathogens, locations of infection, type of infection (prosthetic joint infection, FRI, OM, etc.)] and details on production, formulation, administration, dosing and follow-up time are often missing.

Recently, with the rise of AMR, phage therapy has gained interest in Western Europe, which is displayed by the number of case reports on phage therapy for treatment-resistant musculoskeletal infections (Ferry et al., 2018; Nir-Paz et al., 2019; Onsea et al., 2019; Tkhilaishvili et al., 2019; Vogt et al., 2017). Although these reports described successful outcomes for the combination of phage therapy with antibiotics, they included a multitude of treatment schedules (e.g. routes of administration, applied phage cocktail) (Onsea et al., 2019).

The gold standard for clinical trials is the RCT. According to the authors' knowledge, only one RCT (PhagoBurn trial) was published using topical administration of a phage cocktail in line with GMP guidelines against E.coli and P. aeruginosa in burnwound patients (Jault et al., 2018). The PhagoBurn trial was conducted in burn-wound centres in France and Belgium. This study underlines the importance of phage stability and formulations since phage titres decreased after manufacturing and patients in the experimental group were treated with a lower titer than intended. Although clinical evolution was slower, a relevant reduction in bacterial load with fewer adverse events was still seen in the group that was treated with phage therapy versus the group treated with standard treatment (i.e. sulphadiazine silver cream) for extensive burn wounds (Jault et al., 2018). Recently, further efforts have been made to establish clinical trials using phage therapy, in line with GCP and GMP guidelines, for various infectious conditions (e.g. chronic otitis, infected burn wounds, diabetic foot ulcers, bone and joint infections, chronically infected cystic fibrosis, etc.) (Rohde et al., 2018b). Regarding ODRIs, a research project (PHOSA, Web ref. 2) on phage therapy in multi-drug resistant $S$. aureus musculoskeletal infections and diabetic foot ulcers was commenced. This project aims at producing a potent phage cocktail that is in accordance with GMP guidelines.

\section{Bacteriophage regulations}

Upon their rediscovery, phage preparations were classified as medicinal products in the EU and as drugs in the US, without formal phage-specific requirements or concessions (Verbeken et al., 2012).
Technically speaking, predefined phage products or drugs, which would be produced on an industrial scale, could pass through the classical drug development and marketing pipeline, provided specific adaptations are made. However, phage specificity is bound to make it unlikely that such preparations will be able to timely handle i) the large variety of bacterial pathogens involved in most indications, ii) the time- and geographyrelated changes in the incidence of infectious species and clones, iii) the inevitable emergence of phageresistant bacterial clones (Pirnay et al., 2011).

According to some academic stakeholders, therapeutic phages should be prepared individually (a phage bank) and tested for effectiveness against the pathogens derived from a single patient (a "phagogram"). Intermediary or combined (industrially prepared and personalised phage preparations) approaches may be possible (Pirnay et al., 2011). However, the pharmaceutical legislation was developed to regulate industrially manufactured medicines intended for large-scale distribution, not personalised therapeutic approaches. Accordingly, the currently implemented regulatory framework is not compatible with personalised and sustainable (phage therapy) concepts (Verbeken et al., 2012).

The repeated calls for a specific regulatory framework for phage therapy have not been heard by the European legislator (i.e. EMA), which shows strong resistance to change in this regard (Fauconnier, 2019). Meanwhile, some clinicians and academics are exploring national solutions to accelerate the availability of phages for the treatment of an increasing number of desperate patients. Phage therapy has been performed sporadically in Europe under the umbrella of the Article 37 (Unproven Clinical Practice Interventions) of the Helsinki Declaration. Even though no safety issues were reported and most targeted infections seemed to have been resolved, the small number and diversity of these "Helsinki" phage therapy cases so far did not allow for the unambiguous demonstration that the positive clinical outcome was related to the phage use. In Poland, a member of the EU, phage therapy is considered to be an "Experimental Treatment", covered by the adapted Act of December $5^{\text {th }} 1996$ on the Medical Profession (Polish Law Gazette, 2011, No. 277 item 1634) and the Article 37 of the Declaration of Helsinki (Gorski et al., 2009).

Other phage applications were performed under the umbrella of the "compassionate use", which is a treatment option allowing the use a not yet authorised medicine. Under strict conditions, products under development can be made available to groups of patients who have a disease for which satisfactory authorised therapies are lacking and who cannot participate in clinical trials. In principle, the compassionate approach can only apply to drugs that are being tested or have entered the marketing authorisation application process after the early 
study results have demonstrated efficacy and safety but have not yet been approved. Like the Article 37 of the Helsinki Declaration, the compassionate use treatment option can only be introduced if the drugs - phages in this case - are expected to help in life-threatening or long-term (chronic) and/or seriously debilitating diseases that are not treatable with the currently available therapies. In France, the competent authority has set up a specific committee for phage therapy consisting of (external) experts in various fields. Their task is to specifically evaluate and guide phage therapy requests, discuss them in dialogue with the treating doctors and pass on a consensus advice to the competent authority, which will then authorise the request or not. From 2006 to 2018, 15 patients with osteo-articular, otitis and abdominal infections were treated compassionately with phages in France. Eleven were healed after one treatment with phages (Patey et al., 2018).

On July $5^{\text {th }} 2016$, in response to parliamentary questions regarding the implementation of phage therapy, the Belgian Minister of Social Affairs and Health acknowledged that it is indeed not sensible to treat phages as industrially prepared drugs and, therefore, proposed to investigate the option of magistral phage preparations (Pirnay et al., 2018). The "magistral preparation framework" provides physicians with a practical way of adapting patient treatments to specific needs and making drugs available that are not (yet) available on the market. European and Belgian legislation define a magistral preparation (compound prescription drugs in the US) as "any drug prepared in a pharmacy in accordance with a medical prescription for an individual patient" (Article 3 of Directive 2001/83 of the European Parliament and Article 6 quarter $3 \S$ of the Belgian Medicines Law of March 25 $\left.5^{\text {th }} 1964\right)$. Magistral preparations are made by a pharmacist (or under his/ her supervision) from their constituent ingredients, according to the technical and scientific standards of pharmaceutical technology, for a particular patient, upon a doctor's prescription. Phage APIs to be included in magistral preparations must meet the requirements of a monograph (describing their preparation and quality control testing). In addition, phage APIs must be accompanied by a certificate of analysis, which must be issued by a BAL, quality control laboratories that have been granted an accreditation by the Belgian regulatory authorities to perform batch release testing of medicinal products. On January $10^{\text {th }} 2018$, the phage API monograph received a formal positive advice by the FAMHP and from that date, in Belgium, phages have been delivered in the form of magistral preparations to a selection of patients under the direct responsibility of medical doctors and pharmacists. However, with increasing demand and increasing need, it is time to find a broader solution for the phage therapy regulatory issues. As a next step, supranational competent authorities are urged to adopt the initiatives originally launched by some national regulatory authorities (Fauconnier, 2019).

\section{Conclusion and future perspectives}

The global rise in AMR has heightened the need for alternative antimicrobial strategies. One such strategy that seems very promising is phage therapy. The present review has focused on the current evidence for the application of lytic phages in ODRIs. Not many in vitro phage studies have been performed using ODRI-associated strains, but many studies have proven the ability of phages to inhibit biofilm formation. Furthermore, the available in vivo studies show a high efficacy concerning the eradication of the infection, but the methodology is not comparable between studies. Also, these studies include only monomicrobial infections caused by MRSA or $P$. aeruginosa. Future research with preclinical models of ODRIs caused by other frequently isolated pathogens is required. Clinical studies have shown promising results in patients with severe musculoskeletal infections, including ODRIs. Most of these studies have shown the added value of concomitant antibiotics. Important to note is that the earlier clinical trials conducted in Eastern Europe did not conform to GCP guidelines as known today. More recently, sporadic phage applications have been performed in Western Europe under the umbrella of the Article 37 of the Helsinki Declaration. Even though no safety issues were reported and most targeted infections seemed to have been resolved, the small number and diversity of these "Helsinki" phage therapy cases so far did not allow for the unambiguous demonstration that the positive clinical outcome was related to the phage use. More research including reports on larger patient populations treated with phage therapy are required to fully implement phage therapy in the treatment of ODRIs. Furthermore, national and international regulatory authorities should urgently optimise the regulatory framework for phage therapy.

\section{References}

Abedon ST, Kuhl SJ, Blasdel BG, Kutter EM (2011) Phage treatment of human infections. Bacteriophage 1: 66-85.

Abedon ST, Thomas-Abedon C (2010) Phage therapy pharmacology. Curr Pharm Biotechnol 11: 28-47.

Ackermann H-W, Wegrzyn G (2014) General characteristics of bacteriophages. In: Phage therapy: current research and applications. Editors: Borysowski J, Miedzybrodzki R, Gorski A. Caister Academic Press, Norfolk, UK.

Alves DR, Gaudion A, Bean JE, Perez Esteban P, Arnot TC, Harper DR, Kot W, Hansen LH, 
Enright MC, Jenkins AT (2014) Combined use of bacteriophage $\mathrm{K}$ and a novel bacteriophage to reduce Staphylococcus aureus biofilm formation. Appl Environ Microbiol 80: 6694-6703.

Arciola CR, Campoccia D, Montanaro L (2018) Implant infections: adhesion, biofilm formation and immune evasion. Nat Rev Microbiol 16: 397-409.

Barros J, Melo LDR, Poeta P, Igrejas G, Ferraz MP, Azeredo J, Monteiro FJ (2019) Lytic bacteriophages against multidrug-resistant Staphylococcus aureus, Enterococcus faecalis and Escherichia coli isolates from orthopaedic implant-associated infections. Int J Antimicrob Agents 54: 329-337.

Bondy-Denomy J, Pawluk A, Maxwell KL, Davidson AR (2013) Bacteriophage genes that inactivate the CRISPR/Cas bacterial immune system. Nature 493: 429-432.

Boucher HW, Corey GR (2008) Epidemiology of methicillin-resistant Staphylococcus aureus. Clin Infect Dis 46 Suppl 5: S344-349.

Brady RA, Leid JG, Calhoun JH, Costerton JW, Shirtliff ME (2008) Osteomyelitis and the role of biofilms in chronic infection. FEMS Immunol Med Microbiol 52: 13-22.

Briers Y, Lavigne R (2015) Breaking barriers: expansion of the use of endolysins as novel antibacterials against Gram-negative bacteria. Future Microbiol 10: 377-390.

Brown TL, Petrovski S, Dyson ZA, Seviour R, Tucci $\mathrm{J}$ (2016) The formulation of bacteriophage in a semi solid preparation for control of propionibacterium acnes growth. PLoS One 11: e0151184. DOI: 10.1371/ journal.pone.0151184.

Chan BK, Abedon ST, Loc-Carrillo C (2013) Phage cocktails and the future of phage therapy. Future Microbiol 8: 769-783.

Cisek AA, Dabrowska I, Gregorczyk KP, Wyzewski Z (2017) Phage therapy in bacterial infections treatment: one hundred years after the discovery of bacteriophages. Curr Microbiol 74: 277-283.

Cobb LH, Park J, Swanson EA, Beard MC, McCabe EM, Rourke AS, Seo KS, Olivier AK, Priddy LB (2019) CRISPR-Cas9 modified bacteriophage for treatment of Staphylococcus aureus induced osteomyelitis and soft tissue infection. PLoS One 14: e0220421. DOI: 10.1371/journal.pone.0220421.

Costerton JW, Stewart PS, Greenberg EP (1999) Bacterial biofilms: a common cause of persistent infections. Science 284: 1318-1322.

Cram P, Lu X, Kates SL, Singh JA, Li Y, Wolf BR (2012) Total knee arthroplasty volume, utilization, and outcomes among Medicare beneficiaries, 19912010. Jama 308: 1227-1236.

Cremet L, Corvec S, Bemer P, Bret L, Lebrun C, Lesimple B, Miegeville AF, Reynaud A, Lepelletier D, Caroff N (2012) Orthopaedic-implant infections by Escherichia coli: molecular and phenotypic analysis of the causative strains. J Infect 64: 169-175.

Curtright AJ, Abedon ST (2011) Phage therapy: emergent property pharmacology. J Bioanal Biomed S6. DOI: 10.4172/1948-593X.S6-002.
Czaplewski L, Bax R, Clokie M, Dawson M, Fairhead H, Fischetti VA, Foster S, Gilmore BF, Hancock RE, Harper D, Henderson IR, Hilpert K, Jones BV, Kadioglu A, Knowles D, Olafsdottir S, Payne D, Projan S, Shaunak S, Silverman J, Thomas CM, Trust TJ, Warn P, Rex JH (2016) Alternatives to antibiotics-a pipeline portfolio review. Lancet Infect Dis 16: 239-251.

Dabrowska K, AbedonST (2019) Pharmacologically aware phage therapy: pharmacodynamic and pharmacokinetic obstacles to phage antibacterial action in animal and human bodies. Microbiol Mol Biol Rev 83. pii: e00012-19. DOI: 10.1128/ MMBR.00012-19.

de Mesy Bentley KL, MacDonald A, Schwarz EM, Oh I (2018) Chronic osteomyelitis with Staphylococcus aureus deformation in submicron canaliculi of osteocytes: a case report. JBJS Case Connect 8: e8. DOI: 10.2106/JBJS.CC.17.00154.

Dedrick RM, Guerrero-Bustamante CA, Garlena RA, Russell DA, Ford K, Harris K, Gilmour KC, Soothill J, Jacobs-Sera D, Schooley RT, Hatfull GF, Spencer H (2019) Engineered bacteriophages for treatment of a patient with a disseminated drugresistant Mycobacterium abscessus. Nat Med 25: 730-733.

Defraine V, Schuermans J, Grymonprez B, Govers SK, Aertsen A, Fauvart M, Michiels J, Lavigne R, Briers Y (2016) Efficacy of artilysin Art-175 against resistant and persistent Acinetobacter baumannii. Antimicrob Agents Chemother 60: 3480-3488.

Deghorain M, Van Melderen L (2012) The Staphylococci phages family: an overview. Viruses 4: 3316-3335.

Dufour N, Delattre R, Ricard JD, Debarbieux L (2017) The lysis of pathogenic Escherichia coli by bacteriophages releases less endotoxin than by betalactams. Clin Infect Dis 64: 1582-1588.

Fauconnier A (2019) Phage therapy regulation: from night to dawn. Viruses 11. pii: E352. DOI: 10.3390/v11040352.

Ferry T, Leboucher G, Fevre C, Herry Y, Conrad A, Josse J, Batailler C, Chidiac C, Medina M, Lustig S, Laurent F (2018) Salvage debridement, antibiotics and implant retention ("DAIR") with local injection of a selected cocktail of bacteriophages: is it an option for an elderly patient with relapsing Staphylococcus aureus prosthetic-joint infection? Open Forum Infect Dis 5: ofy269. DOI: 10.1093/ofid/ofy269.

Gabrilska RA, Rumbaugh KP (2015) Biofilm models of polymicrobial infection. Future Microbiol 10: 1997-2015.

Gilbert P, Das J, Foley I (1997) Biofilm susceptibility to antimicrobials. Adv Dent Res 11: 160-167.

Goldfarb T, Sberro H, Weinstock E, Cohen O, Doron S, Charpak-Amikam Y, Afik S, Ofir G, Sorek $R$ (2015) BREX is a novel phage resistance system widespread in microbial genomes. EMBO J 34: 169183.

Goodridge LD (2010) Designing phage therapeutics. Curr Pharm Biotechnol 11: 15-27. 
Gorski A, Miedzybrodzki R, Borysowski J, WeberDabrowska B, Lobocka M, Fortuna W, Letkiewicz S, Zimecki M, Filby G (2009) Bacteriophage therapy for the treatment of infections. Curr Opin Investig Drugs 10: 766-774.

Haddad Kashani H, Schmelcher M, Sabzalipoor H, Seyed Hosseini E, Moniri R (2018) Recombinant endolysins as potential therapeutics against antibioticresistant Staphylococcus aureus: current status of research and novel delivery strategies. Clin Microbiol Rev 31. pii: e00071-17. DOI: 10.1128/CMR.00071-17.

Haddadin AS, Fappiano SA, Lipsett PA (2002) Methicillin resistant Staphylococcus aureus (MRSA) in the intensive care unit. Postgrad Med J 78: 385-392.

Hodyra-Stefaniak K, Miernikiewicz P, Drapala J, Drab M, Jonczyk-Matysiak E, Lecion D, Kazmierczak Z, Beta W, Majewska J, Harhala M, Bubak B, Klopot A, Gorski A, Dabrowska K (2015) Mammalian hostversus-phage immune response determines phage fate in vivo. Sci Rep 5: 14802. DOI: 10.1038/srep14802.

Jault P, Leclerc T, Jennes S, Pirnay JP, Que YA, Resch G, Rousseau AF, Ravat F, Carsin H, Le Floch R, Schaal JV, Soler C, Fevre C, Arnaud I, Bretaudeau L, Gabard J (2018) Efficacy and tolerability of a cocktail of bacteriophages to treat burn wounds infected by Pseudomonas aeruginosa (PhagoBurn): a randomised, controlled, double-blind phase 1/2 trial. Lancet Infect Dis 19: 35-45.

Jikia D, Chkhaidze N, Imedashvili E, Mgaloblishvili I, Tsitlanadze G, Katsarava R, Glenn Morris J Jr, Sulakvelidze A (2005) The use of a novel biodegradable preparation capable of the sustained release of bacteriophages and ciprofloxacin, in the complex treatment of multidrug-resistant Staphylococcus aureus-infected local radiation injuries caused by exposure to Sr90. Clin Exp Dermatol 30: 23-26.

Kaur S, Harjai K, Chhibber S (2014) Bacteriophage mediated killing of Staphylococcus aureus in vitro on orthopaedic K wires in presence of linezolid prevents implant colonization. PLoS One 9: e90411. DOI: 10.1371/journal.pone.0090411.

Kaur S, Harjai K, Chhibber S (2016) In vivo assessment of phage and linezolid based implant coatings for treatment of methicillin resistant $S$. aureus (MRSA) mediated orthopaedic device related infections. PLoS One 11: e0157626. DOI: 10.1371/ journal.pone.0157626.

Kishor C, Mishra RR, Saraf SK, Kumar M, Srivastav AK, Nath G (2016) Phage therapy of staphylococcal chronic osteomyelitis in experimental animal model. Indian J Med Res 143: 87-94.

Kock R, Becker K, Cookson B, van Gemert-Pijnen JE, Harbarth S, Kluytmans J, Mielke M, Peters G, Skov RL, Struelens MJ, Tacconelli E, Navarro Torne A, Witte W, Friedrich AW (2010) Methicillin-resistant Staphylococcus aureus (MRSA): burden of disease and control challenges in Europe. Euro Surveill 15: 19688. DOI: $10.2807 /$ ese.15.41.19688-en.

Kumari S, Harjai K, Chhibber S (2010) Topical treatment of Klebsiella pneumoniae B5055 induced burn wound infection in mice using natural products. J Infect Dev Ctries 4: 367-377.

Kurtz SM, Lau E, Watson H, Schmier JK, Parvizi J (2012) Economic burden of periprosthetic joint infection in the United States. J Arthroplasty 27: 6165.e61.

Kutateladze M, Adamia R (2008) Phage therapy experience at the Eliava Institute. Med Mal Infect 38: 426-430.

Kutateladze M, Adamia R (2010) Bacteriophages as potential new therapeutics to replace or supplement antibiotics. Trends Biotechnol 28: 591-595.

Kutter E, De Vos D, Gvasalia G, Alavidze Z, Gogokhia L, Kuhl S, Abedon ST (2010) Phage therapy in clinical practice: treatment of human infections. Curr Pharm Biotechnol 11: 69-86.

Labrie SJ, Samson JE, Moineau S (2010) Bacteriophage resistance mechanisms. Nat Rev Microbiol 8: 317-327.

Landraud L, Jaureguy F, Frapy E, Guigon G, Gouriou S, Carbonnelle E, Clermont O, Denamur E, Picard B, Lemichez E, Brisse S, Nassif X (2013) Severity of Escherichia coli bacteraemia is independent of the intrinsic virulence of the strains assessed in a mouse model. Clin Microbiol Infect 19: 85-90.

Lang G, Kehr P, Mathevon H, Clavert JM, Sejourne P, Pointu J (1979) [Bacteriophage therapy of septic complications of orthopaedic surgery (author's transl]. Rev Chir Orthop Reparatrice Appar Mot 65: 33-37.

Levin BR, Bull JJ (2004) Population and evolutionary dynamics of phage therapy. Nat Rev Microbiol 2: 166-173.

Loc-Carrillo C, Abedon ST (2011) Pros and cons of phage therapy. Bacteriophage 1: 111-114.

Lungren MP, Christensen D, Kankotia R, Falk I, Paxton BE, Kim CY (2013) Bacteriophage K for reduction of Staphylococcus aureus biofilm on central venous catheter material. Bacteriophage 3: e26825. DOI: $10.4161 /$ bact.26825.

Lusiak-Szelachowska M, Zaczek M, WeberDabrowska B, Miedzybrodzki R, Klak M, Fortuna W, Letkiewicz S, Rogoz P, Szufnarowski K, JonczykMatysiak E, Owczarek B, Gorski A (2014) Phage neutralization by sera of patients receiving phage therapy. Viral Immunol 27: 295-304.

Lusiak-Szelachowska M, Zaczek M, WeberDabrowska B, Miedzybrodzki R, Letkiewicz S, Fortuna W, Rogoz P, Szufnarowski K, JonczykMatysiak E, Olchawa E, Walaszek KM, Gorski A (2017) Antiphage activity of sera during phage therapy in relation to its outcome. Future Microbiol 12: $109-117$.

Maciejewska B, Olszak T, Drulis-Kawa Z (2018) Applications of bacteriophages versus phage enzymes to combat and cure bacterial infections: an ambitious and also a realistic application? Appl Microbiol Biotechnol 102: 2563-2581.

Malik DJ, Sokolov IJ, Vinner GK, Mancuso F, Cinquerrui S, Vladisavljevic GT, Clokie MRJ, Garton NJ, Stapley AGF, Kirpichnikova A (2017) Formulation, 
stabilisation and encapsulation of bacteriophage for phage therapy. Adv Colloid Interface Sci 249: 100-133.

Markoishvili K, Tsitlanadze G, Katsarava R, Morris JG Jr, Sulakvelidze A (2002) A novel sustainedrelease matrix based on biodegradable poly(ester amide)s and impregnated with bacteriophages and an antibiotic shows promise in management of infected venous stasis ulcers and other poorly healing wounds. Int J Dermatol 41: 453-458.

Matsuzaki S, Uchiyama J, Takemura-Uchiyama I, Daibata M (2014) Phage therapy: experiments using animal infection models In: Phage therapy: current research and applications. Editors: Borysowski J, Miedzybrodzki R, Gorski A. Caister Academic Press Norfolk, UK.

Merabishvili M, Monserez R, van Belleghem J, Rose T, Jennes S, De Vos D, Verbeken G, Vaneechoutte M, Pirnay JP (2017) Stability of bacteriophages in burn wound care products. PLoS One 12: e0182121. DOI: 10.1371/journal.pone.0182121.

Metsemakers WJ, Fragomen AT, Moriarty TF, Morgenstern M, Egol KA, Zalavras C, Obremskey WT, Raschke M, McNally MA (2019) Evidence-based recommendations for local antimicrobial strategies and dead space management in fracture-related infection. J Orthop Trauma 34: 18-29.

Metsemakers WJ, Kuehl R, Moriarty TF, Richards RG, Verhofstad MH, Borens O, Kates S, Morgenstern M (2016) Infection after fracture fixation: current surgical and microbiological concepts. Injury 49: 511-522.

Meurice E, Rguiti E, Brutel A, Hornez JC, Leriche A, Descamps M, Bouchart F (2012) New antibacterial microporous $\mathrm{CaP}$ materials loaded with phages for prophylactic treatment in bone surgery. J Mater Sci Mater Med 23: 2445-2452.

Moojen DJ (2013) Exploring new strategies for infection treatment: commentary on an article by Cengiz Yilmaz, MD, et al.: "Bacteriophage therapy in implant-related infections. An experimental study". J Bone Joint Surg Am 95: e11 1-12.

Moriarty TF, Kuehl R, Coenye T, Metsemakers WJ, Morgenstern M, Schwarz EM, Riool M, Zaat SAJ, Khana N, Kates SL, Richards RG (2016) Orthopaedic device-related infection: current and future interventions for improved prevention and treatment. EFORT Open Rev 1: 89-99.

Morris J, Kelly N, Elliott L, Grant A, Wilkinson M, Hazratwala K, McEwen P (2019) Evaluation of bacteriophage anti-biofilm activity for potential control of orthopedic implant-related infections caused by Staphylococcus aureus. Surg Infect (Larchmt) 20: 16-24.

Nir-Paz R, Gelman D, Khouri A, Sisson BM, Fackler J, Alkalay-Oren S, Khalifa L, Rimon A, Yerushalmy O, Bader R, Amit S, CoppenhagenGlazer S, Henry M, Quinones J, Malagon F, Biswas B, Moses AE, Merril G, Schooley RT, Brownstein MJ, Weil YA, Hazan R (2019) Successful treatment of antibiotic resistant poly-microbial bone infection with bacteriophages and antibiotics combination. Clin Infect Dis 69: 2015-2018.

Nishitani K, Sutipornpalangkul W, de Mesy Bentley KL, Varrone JJ, Bello-Irizarry SN, Ito H, Matsuda S, Kates SL, Daiss JL, Schwarz EM (2015) Quantifying the natural history of biofilm formation in vivo during the establishment of chronic implantassociated Staphylococcus aureus osteomyelitis in mice to identify critical pathogen and host factors. J Orthop Res 33: 1311-1319.

Ofir G, Melamed S, Sberro H, Mukamel Z, Silverman S, Yaakov G, Doron S, Sorek R (2018) DISARM is a widespread bacterial defence system with broad anti-phage activities. Nat Microbiol 3: 90-98.

Onsea J, Soentjens P, Djebara S, Merabishvili M, Depypere M, Spriet I, De Munter P, Debaveye Y, Nijs S, Vanderschot P, Wagemans J, Pirnay JP, Lavigne R, Metsemakers WJ (2019) Bacteriophage application for difficult-to-treat musculoskeletal infections: development of a standardized multidisciplinary treatment protocol. Viruses 11. pii: E891. DOI: 10.3390/v11100891.

Papakostidis C, Kanakaris NK, Pretel J, Faour O, Morell DJ, Giannoudis PV (2011) Prevalence of complications of open tibial shaft fractures stratified as per the Gustilo-Anderson classification. Injury 42: 1408-1415.

Patel AA, Buller LT, Fleming ME, Chen DL, Owens PW, Askari M (2015) National trends in ambulatory surgery for upper extremity fractures: a 10-year analysis of the US National Survey of Ambulatory Surgery. Hand (New York, NY) 10: 254-259.

Patey O, McCallin S, Mazure H, Liddle M, Smithyman A, Dublanchet A (2018) Clinical Indications and compassionate use of phage therapy: personal experience and literature review with a focus on osteoarticular infections. Viruses 11. pii: E18. DOI: 10.3390/v11010018.

Patti JM, Allen BL, McGavin MJ, Hook M (1994) MSCRAMM-mediated adherence of microorganisms to host tissues. Annu Rev Microbiol 48: 585-617.

Payne RJ, Jansen VA (2003) Pharmacokinetic principles of bacteriophage therapy. Clin Pharmacokinet 42: 315-325.

Pires DP, Oliveira H, Melo LD, Sillankorva S, Azeredo J (2016) Bacteriophage-encoded depolymerases: their diversity and biotechnological applications. Appl Microbiol Biotechnol 100: 21412151.

Pirnay JP, De Vos D, Verbeken G, Merabishvili M, Chanishvili N, Vaneechoutte M, Zizi M, Laire G, Lavigne R, Huys I, Van den Mooter G, Buckling A, Debarbieux L, Pouillot F, Azeredo J, Kutter E, Dublanchet A, Gorski A, Adamia R (2011) The phage therapy paradigm: pret-a-porter or sur-mesure? Pharm Res 28: 934-937.

Pirnay JP, Verbeken G, Ceyssens PJ, Huys I, De Vos D, Ameloot C, Fauconnier A (2018) The Magistral Phage. Viruses 10. pii: E64. DOI: 10.3390/v10020064. 
Roach DR, Leung CY, Henry M, Morello E, Singh D, Di Santo JP, Weitz JS, Debarbieux L (2017) Synergy between the host immune system and bacteriophage is essential for successful phage therapy against an acute respiratory pathogen. Cell Host Microbe 22: 38-47.e34.

Rohde C, Resch G, Pirnay JP, Blasdel BG, Debarbieux L, Gelman D, Gorski A, Hazan R, Huys I, Kakabadze E, Lobocka M, Maestri A, Almeida GMF, Makalatia K, Malik DJ, Maslanova I, Merabishvili M, Pantucek R, Rose T, Stverakova D, Van Raemdonck H, Verbeken G, Chanishvili N (2018a) Expert opinion on three phage therapy related topics: bacterial phage resistance, phage training and prophages in bacterial production strains. Viruses 10. pii: E178. DOI: 10.3390/ v10040178.

Rohde C, Wittmann J, Kutter E (2018b) Bacteriophages: a therapy concept against multidrug-resistant bacteria. Surg Infect (Larchmt) 19: 737-744.

Ryan EM, Gorman SP, Donnelly RF, Gilmore BF (2011) Recent advances in bacteriophage therapy: how delivery routes, formulation, concentration and timing influence the success of phage therapy. J Pharm Pharmacol 63: 1253-1264.

Salgado CD, Dash S, Cantey JR, Marculescu CE (2007) Higher risk of failure of methicillin-resistant Staphylococcus aureus prosthetic joint infections. Clin Orthop Relat Res 461: 48-53.

Schirmeier E, Zimmermann P, Hofmann V, Biebl M, Gerstmans H, Maervoet VET, Briers Y (2018) Inhibitory and bactericidal effect of Artilysin ${ }^{\circledast}$ Art-175 against colistin-resistant mcr-1-positive Escherichia coli isolates. Int J Antimicrob Agents 51: 528-529.

Slopek S, Weber-Dabrowska B, Dabrowski M, Kucharewicz-Krukowska A (1987) Results of bacteriophage treatment of suppurative bacterial infections in the years 1981-1986. Arch Immunol Ther Exp (Warsz) 35: 569-583.

Stanley SY, Borges AL, Chen KH, Swaney DL, Krogan NJ, Bondy-Denomy J, Davidson AR (2019) Anti-CRISPR-associated proteins are crucial repressors of anti-CRISPR transcription. Cell 178: 1452-1464.e1413.

Summers WC (2001) Bacteriophage therapy. Annu Rev Microbiol 55: 437-451.

Swarts DC, Jore MM, Westra ER, Zhu Y, Janssen JH, Snijders AP, Wang Y, Patel DJ, Berenguer J, Brouns SJJ, van der Oost J (2014) DNA-guided DNA interference by a prokaryotic Argonaute. Nature 507: 258-261.

Tande AJ, Patel R (2014) Prosthetic joint infection. Clin Microbiol Rev 27: 302-345.

ter Boo GJ, Grijpma DW, Moriarty TF, Richards RG, Eglin D (2015) Antimicrobial delivery systems for local infection prophylaxis in orthopedic- and trauma surgery. Biomaterials 52: 113-125.

Teterycz D, Ferry T, Lew D, Stern R, Assal M, Hoffmeyer P, Bernard L, Uckay I (2010) Outcome of orthopedic implant infections due to different staphylococci. Int J Infect Dis 14: e913-918.
Tkhilaishvili T, Winkler T, Muller M, Perka C, Trampuz A (2019) Bacteriophages as adjuvant to antibiotics for the treatment of periprosthetic joint infection caused by multidrug-resistant $P$ seudomonas aeruginosa. Antimicrob Agents Chemother 64. pii: e00924-19. DOI: 10.1128/AAC.00924-19.

Torres-Barcelo C (2018) Phage therapy faces evolutionary challenges. Viruses 10. pii: E323. DOI: 10.3390/v10060323.

Van Belleghem JD, Dabrowska K, Vaneechoutte M, Barr JJ, Bollyky PL (2018) Interactions between bacteriophage, bacteria, and the mammalian immune system. Viruses 11. pii: E10. DOI: 10.3390/v11010010.

Van Belleghem JD, Merabishvili M, Vergauwen B, Lavigne R, Vaneechoutte M (2017) A comparative study of different strategies for removal of endotoxins from bacteriophage preparations. J Microbiol Methods 132: 153-159.

van Duin D, Paterson DL (2016) Multidrugresistant bacteria in the community: trends and lessons learned. Infect Dis Clin North Am 30: 377-390.

Vandersteegen K, Kropinski AM, Nash JH, Noben JP, Hermans K, Lavigne R (2013) Romulus and Remus, two phage isolates representing a distinct clade within the Twortlikevirus genus, display suitable properties for phage therapy applications. J Virol 87: 3237-3247.

Vanvelk N, Morgenstern M, Moriarty TF, Richards RG, Nijs S, Metsemakers WJ (2018) Preclinical in vivo models of fracture-related infection: a systematic review and critical appraisal. Eur Cell Mater 36: 184199.

Verbeken G, Pirnay JP, De Vos D, Jennes S, Zizi M, Lavigne R, Casteels M, Huys I (2012) Optimizing the European regulatory framework for sustainable bacteriophage therapy in human medicine. Arch Immunol Ther Exp (Warsz) 60: 161-172.

Vogt D, Sperling S, Tkhilaishvili T, Trampuz A, Pirnay JP, Willy C (2017) [Beyond antibiotic therapy - Future antiinfective strategies - Update 2017]. Unfallchirurg 120: 573-584.

Weber-Dabrowska B, Mulczyk M, Gorski A (2000) Bacteriophage therapy of bacterial infections: an update of our institute's experience. Arch Immunol Ther Exp (Warsz) 48: 547-551.

WHO (2015) Global action plan on antimicrobial resistance World Health Organization.

Wolcott R, Costerton JW, Raoult D, Cutler SJ (2013) The polymicrobial nature of biofilm infection. Clin Microbiol Infect 19: 107-112.

Wroe JA, Johnson CT, Garcia AJ (2019) Bacteriophage delivering hydrogels reduce biofilm formation in vitro and infection in vivo. J Biomed Mater Res A 108: 39-49.

Yilmaz C, Colak M, Yilmaz BC, Ersoz G, Kutateladze M, Gozlugol M (2013) Bacteriophage therapy in implant-related infections: an experimental study. J Bone Joint Surg Am 95: 117-125.

Yuan Y, Qu K, Tan D, Li X, Wang L, Cong C, Xiu $\mathrm{Z}, \mathrm{Xu}$ Y (2019) Isolation and characterization of a bacteriophage and its potential to disrupt multi-drug 
resistant Pseudomonas aeruginosa biofilms. Microb Pathog 128: 329-336.

Zaczek M, Lusiak-Szelachowska M, JonczykMatysiak E, Weber-Dabrowska B, Miedzybrodzki R, Owczarek B, Kopciuch A, Fortuna W, Rogoz P, Gorski A (2016) Antibody production in response to staphylococcal ms-1 phage cocktail in patients undergoing phage therapy. Front Microbiol 7: 1681. DOI: $10.3389 /$ fmicb.2016.01681.

Zschach H, Joensen KG, Lindhard B, Lund O, Goderdzishvili M, Chkonia I, Jgenti G, Kvatadze N, Alavidze Z, Kutter EM, Hasman H, Larsen MV (2015) What can we learn from a metagenomic analysis of a georgian bacteriophage cocktail? Viruses 7: 65706589.

\section{Web References}

1. https://www.globenewswire.com/newsrelease/2019/10/02/1923936/0/en/ContraFectAnnounces-Plan-for-a-Single-Phase-3-SuperiorityDesign-Study-of-Exebacase-Following-SuccessfulEnd-of-Phase-2-Meeting-with-FDA.html [21.04.20]

2. https://www.pherecydes-pharma.com/ phosa-collaborative-project.html [04.05.20]

\section{Discussion with Reviewer}

Lauren Priddy: How might it be possible to maintain or even predict changes in an MOI over time?

Authors: Modelling/predicting the presence of phage in vivo is extremely difficult, as it is impacted by various parameters, including dose and growth of the bacteria, phage specific traits (basic microbiological traits including burst size and latent period), possible emergence of bacterial phage resistance, potential immunological response by the individual patient, etc.. All these parameters are co-dependent, preventing this modelling with any sense of accuracy. In general, it should be clear that major challenges remain in terms of understanding the dynamics of phage titers in vivo. The involved parameters, including bacterial and phage microbiological traits and individual immunological response, are all interdependent and incompletely understood at the present time.

Editor's note: The Scientific Editor responsible for this paper was Chris Evans. 